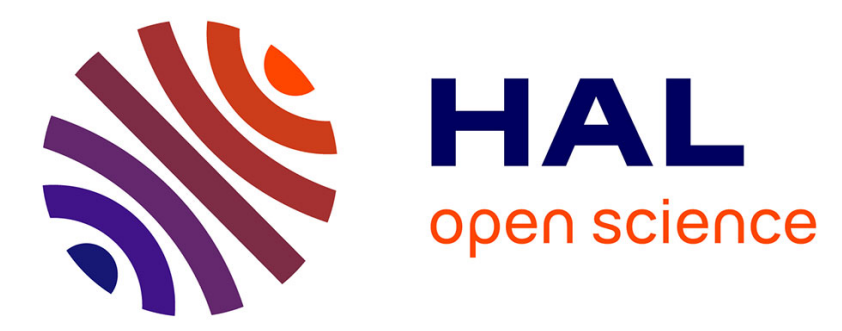

\title{
A model and exploratory field study on team creativity
}

Triparna de Vreede, Imed Boughzala, Gert-Jan de Vreede, Roni Reiter-Palmon

\section{- To cite this version:}

Triparna de Vreede, Imed Boughzala, Gert-Jan de Vreede, Roni Reiter-Palmon. A model and exploratory field study on team creativity. HICSS '12: 45th Hawaii International Conference on System Science, Jan 2012, Maui, Hi, United States. pp.227 - 236, 10.1109/HICSS.2012.66 hal-01225468

\section{HAL Id: hal-01225468 \\ https://hal.science/hal-01225468}

Submitted on 6 Nov 2015

HAL is a multi-disciplinary open access archive for the deposit and dissemination of scientific research documents, whether they are published or not. The documents may come from teaching and research institutions in France or abroad, or from public or private research centers.
L'archive ouverte pluridisciplinaire HAL, est destinée au dépôt et à la diffusion de documents scientifiques de niveau recherche, publiés ou non, émanant des établissements d'enseignement et de recherche français ou étrangers, des laboratoires publics ou privés. 


\title{
A Model and Exploratory Field Study on Team Creativity
}

\author{
Triparna de Vreede ${ }^{1}$, Imed Boughzala ${ }^{2}$, Gert-Jan de Vreede ${ }^{1,3}$, Roni Reiter-Palmon ${ }^{1}$ \\ ${ }^{1}$ The Center for Collaboration Science $\quad{ }^{2}$ Telecom Business School $\quad{ }^{3}$ Systems Engineering Department \\ University of Nebraska at Omaha Institut TELECOM, France Delft University of Technology \\ \{tdevreede; gdevreede; rreiter-palmon\}@unomaha.edu, imed.boughzala@it-sudparis.eu
}

\begin{abstract}
Organizations increasingly rely on teams to solve problems creatively or design new products and services. Research to date has mostly focused on individual creativity, rather than team creativity. This paper introduces the Team Creativity Model (TCM) to understand the antecedents of team creativity. TCM posits that both individual creativity and shared mental models (SMMs) contribute to team creativity. SMMs act as a mediator between knowledge sharing and team creativity. Antecedents to individual creativity include an individual's propensity to be creative and individual knowledge. Individual knowledge also is an antecedent to knowledge sharing, as are an individual's propensity to share knowledge and trust within the team. In an exploratory study at a telecom company, a team of design experts participating in four creative sessions provided initial support for the TCM constructs and their relationships. The findings suggest that further exploratory and empirical research on TCM is justified. Some tentative implications for research and practice are presented.
\end{abstract}

\section{Introduction}

Organizations face problems today that are too complex for one individual or a mono-disciplinary team to solve [41]. Therefore, the past decade has seen an increase in the use of teams by organizations [20]. For instance, in 1999 it was reported that slightly less than $50 \%$ of organizations used teams [15]. Current reports suggest that this figure has jumped to over $70 \%$ of companies in 2003, and $80 \%$ in 2004 [17]. In addition, recent advances in sciences and technologies have enabled organizations to become global. Geographically dispersed locations and multidisciplinary distributed teams have become realistic work arrangements for many modern organizations.

In response to the increased focus on team work, many collaboration techniques and technology solutions have been developed to enable teams to work together productively. Team collaboration refers to the joint effort of team members in achieving a goal. The quality of collaboration in an organization directly affects the organization's outcomes and performance [35]. Team collaboration is important for team functioning when tasks are complex, ambiguous and dynamic [7]. Collaboration is particularly beneficial when the team members are required to be open, share information with others, or be creative.

Team collaboration is especially important at the early stages of the creative process [33]. Creativity is quickly becoming an essential part of non-routine project teams who are tasked with the development of innovative products or services [45]. High levels of market competition, rapid technology developments, and short product life spans, set increasingly challenging requirements to create new product specifications. Thus, team members have to display high levels of creativity in order to remain ahead of the curve [45]. Therefore, organizations are creating project based teams consisting of individuals tasked with generating innovative ideas and then transferring these ideas to create marketable technology, products, and services [34, 62]. Research on the relationship between team collaboration, team creativity, and innovation has shown that having team goals emphasizing collaboration produces more new ideas and results in an improvement of team innovation $[48,51]$.

Despite of the increasing relevance of team creativity, this area has not been extensively researched. Most of the early work on organizational creativity has focused on the individual level. Teams were viewed as a social context within which the individuals function and which could facilitate or inhibit individual creativity $[3,68]$. There are several reasons why the organizations focus on the role of teams in the development of creative products. First, models have been developed that suggest that some team properties can be emergent [42]. Emergence can be defined as a phenomenon that "originates in the cognition, affect, behaviors, or other characteristics of individuals, is amplified by their interactions, and manifests as a higher-level, collective phenomenon" [42, p.55]. This definition suggests that team creativity might be an entirely different process than individual creativity and should not merely be viewed as a background or a social process. Second, a focus on 
team creativity enables teams to capitalize on the social interactions of the team members [61]. Project teams represent a complex social system that may involve multiple stakeholders from different parts of the organization. One of the critical aspects of innovation is the integration of the existing knowledge and ideas into an innovative business model. Studying creativity at the team level allows organizations to better understand the social interactions and allows them to exploit and integrate the expertise of the team members in order to generate more creative ideas. Finally, encouraging team creativity enables team members to share their thoughts and ideas and thereby leading to a shared understanding of the product, market, and customer requirements [21]. Also, team work creates opportunities for the team members to participate in group decision making and problem solving which in turn allows the team members to utilize their varied skill sets and experiences [38].

One of the aspects of team creativity that requires attention concerns the antecedents of team creativity. While it is being accepted that team creativity is beneficial for organizations, there have not been many studies that isolate the factors that encourage or inhibit team creative outputs. It is important to understand the antecedents of team creativity as it will help organizations to create an environment and select team members that maximize the chances of innovation. Without a clear understanding of the factors affecting creativity, organizations cannot effectively utilize the expertise of their teams.

Therefore, the purpose of this paper is to explore and understand the antecedents of team creativity. We present a theoretical model, the Team Creativity Model (TCM), to explain the constructs that affect team creativity. We then evaluate this model through an exploratory field study. Through this field study we compare the constructs and relationships proposed by the TCM with the attitudes, opinions, and reported actions of 8 experts from different areas involving in four creativity sessions within an International Telecom company to come up with a new and innovative cellular phone model.

The remainder of the paper is structured as follows. In the next section we introduce the TCM, a theoretical model of the antecedents of team creativity. This is followed by the details of the field study including the participants and the process of the study. We then provide an analysis of the session transcripts where we discuss different situations and provide examples that provide support for the TCM constructs and their relationships. The paper concludes with a discussion of some tentative implications based on the model's logic, the study's limitations, and directions for future research.

\section{A Model of Team Creativity}

Creativity is often defined in terms of novelty and usefulness. A well accepted definition of creativity is "a product or response that is (a) both a novel and appropriate, useful, correct or valuable response to the task at hand, and (b) the task is heuristic rather than algorithmic in nature” [2]. Creativity can exist both at the individual and team level. There appears to be consensus among researchers that when individuals work together to solve problems creatively, the creativity of the team as a whole will be influenced by the creativity of the individuals that make up the team $[19,63]$. However, the extent of this influence is debated. Some researchers argue that team creativity can simply be considered as the combined creativity of the individual team members [19]. Other researchers posit that the collaboration between the team members may lead to higher levels of team creativity than can be explained by the combined individual creativity levels: Combining contributions from the individual team members may lead to richer, more creative ideas at the team level [60]. Yet, team creativity results not just from combining individual ideas. Team creativity occurs during a social process of sense-making and collaboration where one individual's actions may inspire the team to devise and follow a more creative process to address the problem at hand resulting in higher levels of creativity $[60,63]$. The Team Creativity Model (TCM) that we introduce below adopts the second perspective, i.e. that team creativity is more than just the combined creativity of the individual team members.

Following Amabile's [2] definition of individual creativity, we define team creativity as the extent to which a team's ideas in response to a problem solving task are both novel and useful. TCM posits that team creativity is directly influenced by individual creativity. The extent to which individual members of a team are capable to generate creative ideas will determine the creativity of the team as a whole since the individual contributions provide the team with its 'raw' materials (see e.g. [54]). Furthermore, creative individuals, experts in particular, are less likely to have difficulties or be uncomfortable expressing themselves, even under less than optimal conditions [11]. Thus, if teams have higher proportion of creative individuals who are experts, such teams will be more likely to have a high degree of team creativity. However, it is important that the members of the creative team are channeled to express themselves properly and process loss is limited during their discussions as this may 
result in less than optimal conditions for individual team members to express themselves $[36,69,70]$.

An individual's personality or propensity to be creative is an important determinant for individual creativity. Research shows that aspects of individual ability, personality, motivational variables, and certain cognitive processes are strongly associated with individual creativity [22,31,50]. Another study revealed that students who were more creative were also rated by their peers to be more sociable and popular than their non-creative counterparts [53].

Along with personality and social variables that enable groups to be creative, skill sets which encourage creativity also add to the creative propensity of the individual. Amabile [2] identified creativity relevant skills to include skills to break the most commonly used perceptual concepts and be able to abandon the most commonly used strategies and move in new directions. People who could look at problems with a new strategy and approached the problem with a blank canvas were better able to get creative [23]. Another characteristic that enabled individuals to be creative was the capability to suspend judgment and use wide categories while coming up with creative ideas $[12,58]$. Finally, individuals who remembered large amounts of information more accurately also had the capability to be more creative than their counterparts [9].

Creativity is also influenced by an individual's knowledge in his/her own discipline. Expertise and domain knowledge have been found to be important contributors to creativity [18,65]. Complete novices tend to be less creative at first but as they gain knowledge, their creativity increases rapidly [55]. However, this relationship is not linear; it is curvilinear. To a certain point, as expertise increases, so does the individual creativity. Yet increased expertise at some level tends to close people off to options that are beyond their area of expertise and they start to depend on a broad array of conservative options that have been successful in the past [55].

Individual knowledge not only influences individual creativity, but also affects the amount of knowledge sharing that takes place in a team. Knowledge sharing occurs when group members voluntarily exchange information with the purpose of reaching a broader understanding of their group goal and its accomplishment [24]. One of the core drivers of creativity in organizations is the knowledge-based view where project teams are used as instruments for integrating tacit and explicit knowledge among the team members [27]. While possession of knowledge is at an individual level, it is important to integrate the knowledge of the individuals into a collective knowledge for the project to benefit from it [63].
Knowledge sharing is critical for creative teams. The type of knowledge that is most likely to be important for creative teams is the one that is unique to each team member based on his/her area of expertise. Groups that are able to consider more information from diverse sources are more likely to arrive at better solutions than individuals working on their own [24]. Inadequate knowledge sharing leads to less than optimum problem solving by the group because individual group members are not able to evaluate a problem comprehensively with the limited information available to them [43]. In order to solve a problem most effectively, all information relevant to the problem has to be taken into account [43], and group members need to actively exchange information with each other in order to access that information [56,64].

However, research indicates that the process of sharing knowledge that is not common is difficult. Group members often tend to repeat the information known to all group members as the discussion progresses and do not share information that is not widely known $[44,57,67]$. Moreover, it has been found that the amount of perceived expertise of the group members influences the knowledge sharing taking place in the group [13]. In other words, individuals with higher levels of expertise are more willing to share their knowledge with their team mates than their less experienced counterparts. Conversely, when individual team members do not perceive themselves to be experts in their discipline, they are less likely to offer their unique observations to the group and contribute to knowledge sharing.

Trust is an important antecedent to knowledge sharing [16,52]. Research shows that increased trust allows team members to share knowledge more effectively [16]. Trust not only influences the degree of knowledge sharing, that is, how willing team members are to share the knowledge they have, but also how the knowledge is viewed and integrated by other team members [1]. Lack of trust is sometimes an issue with because of such team's diverse makeup. As a result these teams may suffer from less than optimal communication and interactions.

In addition to trust, individuals must have a propensity to share knowledge in order to make the knowledge sharing a part of the team routine. But, there are various factors that may affect this desire to share information. Information is shared differently among group members who are familiar with each other than those who are not, which in turn affects the problem solving capabilities of the group [28]. There are also certain social dilemmas associated with knowledge sharing which might impact the propensity to share knowledge. For example, if some of the group members have spent considerable time and resources to 
gather the knowledge, they might be unwilling to share that knowledge in a group setting [8]. In particular when it is unclear what they can gain in exchange [6].

TCM posits that knowledge sharing does not contribute to team creativity directly but it contributes to the development of Shared Mental Models (SMMs), which in turn influences team creativity. SMMs are representations of knowledge structures that are shared among team members [10, 40]. These shared structures enable the team members to find a common ground to describe, explain, and predict the events that occur in their environment [47]. SMMs can be divided primarily into four areas: (a) knowledge about equipment and tools; (b) knowledge about the team task, goal, and performance requirements; (c) knowledge about other team members' abilities, knowledge, and skills; and (d) knowledge about appropriate team interactions [10]. The majority of research on SMMs has focused on one of the above dimensions or has consolidated them into two dimensions, namely, task and team shared mental models.

Even though research on SMMs and team creativity is limited, existing empirical studies suggest that SMMs have a positive relationship with creativity both at individual and team level. For example, Mumford et al. [41] found that when shared mental models are developed through sharing the same training program, they facilitate higher levels of creative idea generation within the team. Similarly, Pearce and Ensley [51] found shared vision to be positively related to product and process innovation ideas in teams. In a related study, Gilson and Shalley [26] found that increasing the number of shared goals in a team not only resulted in an increase in the creativity but also increased the engagement of the team members in the creative process. However, SMMs are not static. They may not initially be present in a group (see e.g. [71]) and they are developed over time through discussion of issues, sharing knowledge, and learning from past mistakes and successes $[7,46,66]$.

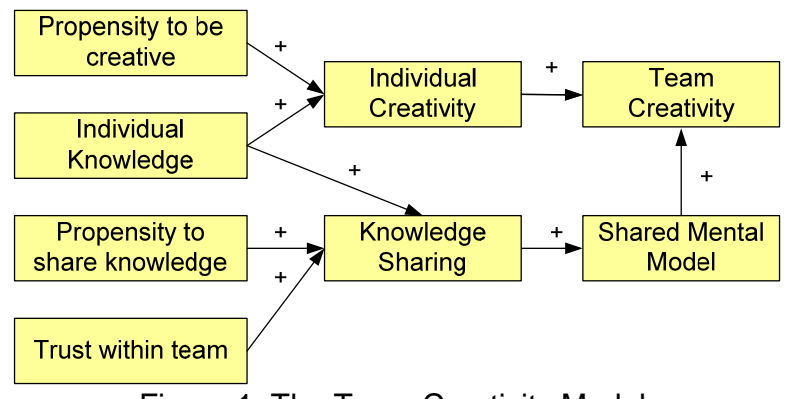

Figure 1. The Team Creativity Model.
Based on the above discussion, figure 1 depicts the various antecedents and their relationships proposed by the TCM. The next section introduces an exploratory field study with experts from an international telecom company in France that was executed to find support for the TCM constructs and their relationships.

\section{Method}

\subsection{Participants}

Eight experts from a telecom company participated in each of four creativity sessions (Table 1). The involvement of industry experts in these sessions [20] allowed us, in the words of Hevner et al. [16] p. 80) "to combine relevance and rigor by meeting a business need with applicable knowledge." Each participant held a master degree and three had earned PhDs. Their degrees were in a variety of disciplines: Industrial Design, Engineering, Management, Marketing, Sociology, Computer Science, and Telecom. Participants worked for different departments, including Strategic Marketing, Telecom Solutions, Sales, R \& D, Quality, and IT. Their work experience ranged from 10 to 24 years. Their average age was 42 and $62 \%$ were male. The participant names are withheld for privacy reasons. Their statements are identified only by their ID and their department. The name of the company and the sessions' factual deliverables are confidential.

Table 1: Participants' demographic data.

\begin{tabular}{|c|c|c|c|c|c|c|c|}
\hline ID & Area & Dept. & Age & Sex & Background & Degree & $\begin{array}{l}\text { Work } \\
\text { exp. }\end{array}$ \\
\hline E1 & Marketing & \begin{tabular}{|l|} 
Strategic \\
Marketing
\end{tabular} & $35-39$ & $\mathrm{~F}$ & $\begin{array}{l}\text { Marketing \& } \\
\text { Sociology }\end{array}$ & MBA & $10-14$ \\
\hline E2 & $\begin{array}{l}\text { Interface } \\
\text { Design }\end{array}$ & R \& D & $40-44$ & $M$ & \begin{tabular}{|l} 
Industrial \\
Design
\end{tabular} & MSc & $15-19$ \\
\hline E3 & $\begin{array}{l}\text { Electronic } \\
\text { engineering }\end{array}$ & \begin{tabular}{|l|} 
Telecom \\
Solutions
\end{tabular} & $40-44$ & M & Engineering & MSc & $15-19$ \\
\hline E4 & $\begin{array}{l}\text { Telecom } \\
\text { Engineering }\end{array}$ & $\begin{array}{l}\text { Telecom } \\
\text { Solutions }\end{array}$ & $40-44$ & $M$ & Telecoms & $\mathrm{PhD}$ & $15-19$ \\
\hline E5 & Software & IT & $40-44$ & M & Comp.Sci. & $\mathrm{PhD}$ & $15-19$ \\
\hline E6 & $\begin{array}{l}\text { Network } \\
\text { architecture }\end{array}$ & IT & $40-44$ & M & Telecoms & MSc & $15-19$ \\
\hline E7 & $\begin{array}{l}\text { Quality of } \\
\text { Service }\end{array}$ & Quality & $40-44$ & $\mathrm{~F}$ & $\begin{array}{l}\text { Telecoms \& } \\
\text { Ergonomics }\end{array}$ & $\mathrm{PhD}$ & $15-19$ \\
\hline E8 & $\begin{array}{l}\text { Sales and } \\
\text { CRM }\end{array}$ & Sales & $45-49$ & $\mathrm{~F}$ & Management & MBA & $20-24$ \\
\hline
\end{tabular}

\subsection{Procedures}

Participants worked together during four sessions over a four-month period between October 2009 and January 2010 to co-design an innovative cellular phone model. Each session lasted three hours and was facilitated by one of the authors. All sessions were 
conducted in French. Graduate assistants recorded the sessions and made field notes about critical incidents and verbal statements. Participants recorded their key contributions on Post-It notes, and gave them to the research team at the end of each session. The facilitator made field notes immediately following every session. At the end of each session, participants were asked to provide their personal perceptions about the team creativity process and the intermediate and final deliverables (the cellular phone model).

To minimize the possibility of observation bias, we did not seed the participants with direct questions pertaining to the TCM constructs. Rather, we observed interactions among participants and documented their feedback. The session observers were not briefed on the TCM constructs until after the sessions were over.

\subsection{The Creativity Method}

The sessions used a specific creativity method, the Concept-Knowledge (C-K) method [30] and a structured facilitation process. The C-K method helps individuals and teams to innovate by constraining them to get out of the box when they aim to create a new solution, product, or service. The method is based on the concept of "expandable rationality" [29, 30]. It allows training people to avoid design illusions, memorizing the history of a design process, and structuring team work in innovative design projects. The participants were not familiar with this type of creativity methods.

The C-K method views expansion as a key focus in a design project. There are two expandable spaces: The Knowledge space (K), consisting of logical propositions relevant to the design project. These propositions are used to formulate new concepts or expand existing concepts. The Concept space (C), consisting of objects that meet some desired design requirements that do not exist yet. These objects typically represent the goal of design activities. The C$\mathrm{K}$ design process lets the $\mathrm{C}$ and $\mathrm{K}$ spaces co-evolve by (1) allowing concepts in the C-space to expand with new properties based on propositions from the $\mathrm{K}$ space, and (2) expanding knowledge in the K-space through new insights from the experiences with the concepts that result from the design process. For further details on the C-K method, please refer to [25, 30].

\subsection{Creativity Sessions}

The main goal of the four creativity sessions was to "imagine" and design a new cell phone model without a SIM card (based on the Cloud Computing developments). Each creativity session focused on one step of the C-K method. First, a cell phone was initially defined to consist of the following components: Screen, Keyboard, Microphone, Earphone, Transceiver/antenna, SIM card, Operating System, Services/Apps, and Camera. Second, the SIM card concept was removed. The participants had to try to expand the other components such that they would fulfill the requirements of the new phone model. Finally, the participants had to integrate the expanded components such that they would envision a new cell phone model that still offered the same functionality of a traditional cell phone.

Each session was organized at a different department. Tables and chairs were arranged in a U shape to facilitate eye contact between the participants. Each session opened with a brief presentation by the facilitator to introduce the session agenda and to summarize progress so far in process. Participant also received guidelines on how to share their ideas by writing them on Post-It notes and on justifying their ideas with precise arguments and/or concrete examples. Participants then generated, clarified, reduced, organized, and evaluated ideas concerning the new cell phone design. At the end of each session, participants were asked to provide feedback about the team work and the execution of the C-K method.

Specific details on each of the four sessions are provided in table 2 . The final deliverable from the four sessions was a specification report for the new cellular phone model.

Table 2. Details of the creativity sessions.

\begin{tabular}{|c|l|}
\hline Session & Focus \\
\hline 1 & $\begin{array}{l}\text { Recent cell phone trends and evolutions in } \\
\text { telecom industry. Key cell phone adoption and } \\
\text { marketing drivers. }\end{array}$ \\
\hline 2 & $\begin{array}{l}\text { Removal of SIM card concept. Expansion of } \\
\text { remaining concepts. Technical feasibilities } \\
\text { and constraints related to design, cost, legal, } \\
\text { health, and market concerns. }\end{array}$ \\
\hline 3 & $\begin{array}{l}\text { Development of solutions and scenarios based } \\
\text { on technical possibilities, market situations, } \\
\text { and competitors. }\end{array}$ \\
\hline 4 & $\begin{array}{l}\text { Evaluation of previously formulated solutions } \\
\text { and scenarios. Selection of final solution. } \\
\text { Project debrief. }\end{array}$ \\
\hline
\end{tabular}

\subsection{Analysis}

The facilitator and graduate assistants transcribed the sessions' Post-It notes and field notes into a collection of utterances identified by contributor. They then anonymized this data by replacing the contributors' names with their respective ID. The 
facilitator then coded the utterances according to the TCM constructs. The utterances were also translated into English and validated by someone fluent in both English and French. An English-speaking researcher then also coded the utterances according to the TCM constructs. There was substantial concurrence between the French and English coding. The few discrepancies were resolved through discussion.

\section{Results}

This section presents an analysis of the session transcripts in light of the constructs and relationships proposed by TCM. Many of the utterances from the participants about propensity to share, propensity to create, knowledge sharing, shared mental model, individual and team creativity were consistent with the constructs and relationships proposed by TCM. This section presents qualitative support for that assertion.

\subsection{Antecedents to knowledge sharing}

Propensity to share knowledge, trust within team, and individual knowledge are the three antecedents of knowledge sharing as identified by the TCM. The presence of these antecedents was examined in the sessions with the experts. Results show support for the role of trust in sharing knowledge. It was obvious in most sessions that trust played a significant role in establishing an environment where the experts could share their knowledge easily. Many experts commented to that effect. For example, one of them said "The fact is that we belong to the same company helps to build mutual trust... sharing was almost natural". Another expert from the Quality department mentioned, "An innovation process goes smoothly and quickly when people are in good agreement, have trust in each other." However, initial levels of trust may have been relatively lower. The team appeared to have built trust over time and they seemed to be cognizant of the changes that took place in the team. Said one of the experts from the telecom department "Gradually, as the work progresses during the sessions, a team spirit was established and trust took place between us from different departments."

There was also support that a propensity to share knowledge is required for knowledge sharing. This was evidenced in the following comment "Creativity may seem like an individual concern but eventually it's well done in teams if people are willing to share/combine their knowledge and expertise." Interestingly, the experts mostly commented on the propensity to share knowledge in combination with the importance of possessing individual knowledge. For example, one of the experts mentioned, "It is not only the matter of willingness to share...but also having something to share and being able to do it". This sentiment was echoed in another session where it was said that "The willingness to share comes first and you must have knowledge and be able to share it ... the method helps a lot for that".

A number of experts also appeared to suggest an association between individual knowledge and knowledge sharing. Experts felt that team creativity requires knowledge sharing when people combine their individual knowledge: "In our business, creativity is no longer an individual concern but the collaboration/pooling of several specialties and skills." As evidenced by a comment from an expert from the IT Department, for knowledge sharing to take place, it does require the presence of individual knowledge: “...having something to share to be able to share." In fact, some experts believed that individual knowledge would only become valuable in a team project if it is shared. Said one expert from the R \& D Department, "Knowledge is the only resource which has more value when you share it".

\subsection{Antecedents to individual creativity}

Propensity to be creative and individual knowledge were also assessed in the sessions as antecedents to individual creativity. We found support for the propensity to be creative and moderate support for individual knowledge being an antecedent for creativity at an individual level. While talking about creativity, one of the experts mentioned, "To get out of the box, one must be ready for that" meaning that they should also have the attitude to be creative. Another expert from a different department had something similar to say about his department, "We can say that people were willing and predisposed to create an innovative solution". The experts not only mentioned the predisposition to be necessary, they also noticed the importance of propensity to be creative after the sessions were over: "This is a difficult but exciting exercise ... when we see the outcome, it's impressive for a short time ... eventually one have to be predisposed to it."

Support for individual knowledge as an antecedent to individual creativity came from comments such as "In this creativity session, trust and challenge were always our Leitmotiv [i.e. guiding theme] ...we also should have the good knowledge to share”. They also commented on the selection of the experts as they contributed to the knowledge pool. For example, one of the experts said, "The choice of experts was important ...”. 


\subsection{Individual creativity as an antecedent to team creativity}

Individual creativity was named as one of the antecedents to team creativity in the TCM. This was illustrated on several occasions during the creativity sessions providing support to the model. One of the experts from the sales department mentioned that $" 1+1=3 \ldots$ it's more than the sum of everyone's knowledge" to point out the fact that the combination of individual creativity produced a synergy when working in teams. The experts from different sessions were also in agreement that creativity has become more than an individual endeavor. Comments like "In our business, creativity is no longer an individual concern but the collaboration/pooling of several specialties and skills" illustrate this fact. Some experts also mentioned their support of combining individual creativity to achieve a team outcome: "Creating is always easier collectively."

The participants also seemed to be impressed with the amount of creative ideas that were generated by the use of experts from different departments. For example, one of the participants mentioned "The choice of experts was important ... I believe that they are all creative and sensitive to knowledge sharing and creativity". Other comments that were received in support of this attitude were "I'm not sure we could be able to achieve the same result with a single point of view, in the same department ... especially in such a short time" and "The fact that the group is mixed... Views are complementary and rich that helps to innovate", and "The team was balanced ... each of us brought a stone to the edifice".

\subsection{Knowledge sharing and shared mental models as antecedents to team creativity}

Knowledge sharing and shared mental models are the antecedents to team creativity in the TCM. Shared mental models directly influence team creativity, while the shared knowledge influences team creativity through shared mental models. We found support for both relationships. The experts involved in the creativity sessions acknowledged the importance of knowledge sharing in the creation of an SMM. To this effect, one of the experts commented "This (creativity sessions) strengthens our interest to sharing our knowledge capital and create mental schemas". Another expert mentioned "I did not think that people would be able to share their knowledge so easily and with a goodwill... converging their so different points of view". The participants were aware of the process that took place in order to create a shared mental model. They expressed sentiments like "In the beginning, there was some uncertainty in the project... but once we have advanced in the process of the method, there was a reconciliation (shared understanding) ... the method proved useful and credible for everybody". They were also impressed by the effect of knowledge sharing on team creativity. Said one expert, “... sharing our knowledge and knowhow was the only way for us to be able to create together." One of the experts expressed his surprise at the degree of creativity resulting from the knowledge sharing exercise by saying "I've never imagined the usefulness of this method by constraining us to surpass and force ourselves to be creative together despite our differences".

The experts also acknowledged the importance of shared mental models in the team creativity outputs. Their understanding of the influence of shared mental models on team creativity was reflected by comments such as "Innovation process goes smoothly and quickly when people ... have the same aspirations and perceptions" and "In this exercise, everyone must be on the same wavelength ("the same tempo")". The experts even accepted and welcomed the challenges of working with people from different departments so that they could benefit from the rewards of team creativity once a shared mental model was established. Comments like "We do not have the same vocabulary, the same concerns and the same points of view... but we were able to work together and innovate" and "The time we spent together was very challenging to overcome our differences ... yet it was the source of our strength to be able to create, illustrate that point.

\section{Discussion and conclusions}

This paper advances the Team Creativity Model (TCM) as an explanation to understand the antecedents of team creativity. TCM posits that both individual creativity and SMMs contribute to team creativity. SMMs acts as a mediator between knowledge sharing and team creativity. Antecedents to individual creativity include an individual's propensity to be creative and individual knowledge. Individual knowledge also is an antecedent to knowledge sharing, as are an individual's propensity to share knowledge and trust within the team. During an exploratory study in a telecom company, experts that participated in four creative design sessions provided initial support for the TCM constructs and their relationships. These findings suggest that further exploratory research is merited. They also allow us to tentatively present a number of implications for research and practice.

TCM is based on a synthesis of research efforts on various aspects of individual and team creativity. The 
model and related field data suggest that studying team creativity requires careful consideration of a complex set of constructs and relationships. To empirically study team creativity, we need to consider not only individual creativity, but also important antecedents to individual creativity and the development of SMMs during the creative team process. Further, it can be argued that a deeper understanding of nature of relationships between constructs required. For example, what is the exact nature of the relationship between SMMs and team creativity? Do SMMs just lead to higher idea generation productivity in teams? Or, do SMMs just facilitate the selection of the most creative ideas? Or do they support both idea generation and selection? In fact, it has been suggested that SMMs may lead to too much similarity and therefore conformity [10]. It is possible that some degree of dissimilarity in SMMs or less sharedness would be beneficial especially for team creativity and innovation. The same questions can be raised with respect to knowledge sharing: What is the optimal level of knowledge sharing to support the formation of SMMs?

Our model and findings also provide insights for organizations that employ teams in creative problem solving activities. In particular, it can be argued that if the logic of TCM holds, then organizations must investigate strategies to increase the formation of SMMs and the amount of knowledge that is shared. Several such strategies have been suggested. For example, discussion and planning have been proposed as a strategy to facilitate the formation of SMM. Through discussion and planning, team members become aware of more aspects on how the creative task has to be executed, the role of different members, and possible difficulties each person may need to address. Indeed, Stout, Cannon-Bowers, Salas, and Milanovich [59] have found that planning is a way to develop shared mental models that facilitate team performance. Organizations can also structure interventions to bring about social dynamics that increase the level of knowledge sharing [8]. One such intervention would be to restructure group rewards such that there are greater payoffs for contributing. Another intervention can be to increase the sense of group efficacy as well as the perception of the impact that individuals believe their contributions have on the group. To illustrate this point, Kerr [37] showed that the knowledge sharing in a group reduced when the group size increased and group member's perception of their contribution decreased. A final intervention focuses on establishing a sense of group identity through increased communication among team members [14]. When individuals feel that they are part of a group, they are more likely to share information [5].
The following limitations have to be taken into account when interpreting the results of this study. First, the support for the TCM proposed in this paper originated from limited field observations and expert feedback from a single organization. While no data appeared to challenge the TCM or hint at other constructs, further data collection from organizations in different sectors or from cross-organizational collaborations is required to more broadly examine the extent to which the constructs of TCM manifest in the field. Such data collection should also focus on the development of constructs over time, e.g. adjustments in participants' SMMs. Second, although the field data offers support that the TCM constructs are related, the nature of exploratory study is such that it cannot assert causality. Therefore, further theoretical research and empirical studies are required to find support for causal relationships between TCM constructs. Finally, it was not possible through this field study to actually measure the individual TCM constructs, in particular individual creativity and team creativity. Such measurements would have been useful to gain a deeper understanding of the relationship between individual and team creativity as well as between other TCM constructs.

We envision a number of avenues for further research. First, given the findings reported in this paper, it will be necessary to explore the TCM more fully through additional qualitative studies with different creative problem solving or design teams. Second, some initial confirmatory quantitative studies can also be designed to use Structural Equation Modeling [4] to investigate the relationships between TCM constructs and the mediation relationship between knowledge sharing and SMMs. Finally, it would be useful to examine the fundamental assumption that give rise to the development of the TCM, i.e. that team creativity ultimately leads to higher innovation quality.

\section{References}

[1] Abrams, L., Cross, R., Lesser, E., \& Levin, D. (2003). Nurturing interpersonal trust in knowledge-sharing networks. Academy of Management Executive, 17, 64-77.

[2] Amabile, T. M. (1983). The social psychology of creativity. NY: Springer-Verlag.

[3] Amabile, T. M. (1996). Creativity in context: Update to the social psychology of creativity. Boulder, CO: Westview Press.

[4] Bollen K. A. (1989). Structural Equations with Latent Variables, Wiley.

[5] Bonacich P., \& Schneider, S. (1992). Communication networks and collective action. In W. Liebrand, D. Messick, H. Wilke (Eds.) A Social Psychological Approach to Social Dilemmas, (pp. 128-278), Oxford: Pergammon. 
[6] Boughzala I., Briggs R. O. (2011). Knowledge sharability in cross-organizational collaboration: an exploratory field study, $44^{\text {th }}$ Hawaii International Conference on System Sciences, IEEE Computer Society, 4-7 January 2011, Kauai, Hawaii.

[7] Burke, C., Stagl, K., Salas, E., Pierce, L., \& Kendall, D. (2006). Understanding team adaptation: A conceptual analysis and model. Journal of Applied Psychology, 91, 1189-1207.

[8] Cabrera, A. \& Cabrera, E.F. (2002). Knowledge-Sharing Dilemmas, Organization Studies, 23, 687- 710.

[9] Campbell, D. T. (1960). Blind variation and selective retention in creative thought as in other knowledge processes. Psychological Review, 67, 380 - 400.

[10] Cannon-Bowers, J. A., Salas, E., \& Converse, S. A. (1993). Shared mental models in expert team decision making. In N. J. Castellan, Jr. (Ed.), Current issues in individual and group decision making (pp. 221-246). Hillsdale, N J: Erlbaum.

[11] Collaros, P. A., Anderson, L. R. (1969). Effect of perceived expertness upon creativity of members of brainstorming groups. Journal of Applied Psychology, 53, 159-163.

[12] Cropley, A. (1967). Creativity. London: Longmans

[13] Davenport, T. H., De Long, D. W. \& Beers, M. C. (1998). Successful knowledge management projects. Slogan Management Review, 36, 43-57.

[14] Dawes, R. M. (1991). Social Dilemmas, economic selfinterest, and evolutionary theory. In D. R. Brown \& J. E. K. Smith (Eds.), Frontiers of mathematical psychology: Essays in honor of Clyde Coombs. New York: Springer-Verlag.

[15] Devine, D.J., Clayton, L.D., Phillips, J.L., Dunford, B.B., \& Melner, S.B. (1999). Teams in organizations: Prevalence, characteristics, and effectiveness. Small Group Research, 30, 678- 711.

[16] Edmondson, A. (1999). Psychological safety and learning behavior in work teams. Administrative Science Quarterly, 44, 350-383.

[17] Edmondson, A.C., \& Roloff, K.S. (2009). Overcoming barriers to collaboration: Psychological safety and learning in diverse teams. In: E. Salas, G.F. Goodwin, C.S. Burke, (Eds.) Team effectiveness in complex organizations: Cross-disciplinary perspectives and approaches. New York: Routledge/Taylor \& Francis Group.

[18] Ericsson, K. A. (1999). Creative expertise as superior reproducible performance: Innovative and flexible aspects of expert performance, Psychological Inquiry, 10, 329-333.

[19] Pirola-Merlo, A., \& Mann, L. (2004). The relationship between individual creativity and team creativity: aggregating across people and time. Journal of Organizational Behavior, 25, 235-257.

[20] Galbraith, J. R. (2009). Designing matrix organizations that actually work. San Francisco, CA: Jossey Bass

[21] Gardner, H. (1988). Creativity: An interdisciplinary perspective. Creativity Research Journal, 1, 8-26.

[22] George, J. M. (2007). Creativity in organizations. In J. P. Walsh \& A. P. Brief (Eds.), Academy of Management annals, 1, 439 - 477. New York: Erlbaum.
[23] Getzels, J. W, \& Csikszentmihalyi, M. (1976). The creative vision: A longitudinal study of problem finding in art. New York: Wiley.

[24] Gigone, D., \& Hastie, R. (1993). The common knowledge effect: Information sharing and group judgment. Journal of Personality and Social Psychology, 65, 959-974.

[25] Gillier, T., Piat, G., Roussel, B., \& Truchot, P. (2010).Managing innovation fields in a cross-industry exploratory partnership with C-K design theory. Journal of Product Innovation Management, 27, 883-896.

[26] Gilson, L., \& Shalley, C. (2004). A little creativity goes a long way: An examination of teams' engagement in creative processes. Journal of Management, 30. 453- 470.

[27] Grant, R. M. (1996). Prospering in dynamically competitive environments: Organizational capability as knowledge integration, Organization Science, 7, 375-387.

[28] Gruenfeld, D. H., Mannix, E. A., Williams, K. Y., \& Neale, M. A. (1996). Group composition and decision making: How member familiarity and information distribution affect process and performance. Organizational Behavior and Human Decision Processes, 67, 1-15.

[29] Hatchuel A., Le Masson P., \& Weil B. (2008). Studying creative design: The contribution of C-K theory. Studying Design Creativity. NSF International Workshop on Studying Design Creativity'08, University of Provence, Aix-en-Provence, 10-11 March 2008.

[30] Hatchuel A., Weil B. (2002). C-K theory: Notions and applications of a unified design theory. Proceedings of the Herbert Simon International Conference on "Design Science” Lyon, 15-16 March 2002.

[31] Hennessey, B. A., \& Amabile, T. M. (2010). Creativity. Annual Review of Psychology, 61, 569-598.

[32] Hevner A. R., S. T. March, J. Park, and S. Ram, "Design Science in Information Systems Research", MIS Quarterly, Vol. 28 No. 1/March 2004.

[33] Hoegl, M., Weinkauf, K, \& Gemuenden, H. G. (2004). Interteam Coordination, Project Commitment, and Teamwork in Multiteam R \& D Projects: A Longitudinal Study, Organization Science, 15, 38-55.

[34] Iansiti, M. \& West J. (1997), Technology Integration: Turning Great Research into Great Products,” Harvard Business Review, 75, 69-79.

[35] Jordan, P. J., Ashkanasy, N. M., Härtel, C. E. J., \& Hooper, G. S. (2002). Workgroup emotional intelligence: Scale development and relationship to team process effectiveness and goal focus. Human Resource Management Review, 12, 195-214.

[36] Kerr, N. L., \& Tindale, R. S. (2004). Group performance and decision making. Annual Review of Psychology, 55, 623-655.

[37] Kerr. N. L. (1992). Group decision making at a multialternative task: Extremity, interaction distance, pluralities, and issue importance. Organizational Behavior and Human Decision Processes, 52, 64-95.

[38] King, N., \& Anderson, N. (1990). Innovation in Working Groups. In M. A. West and J. L. Farr (Eds.), Innovation and Creativity at Work. New York: Wiley,

[39] Kitzinger, J., “Introducing focus groups”, British Medical Journal, 1995, 311, 299-302. 
[40] Klimoski, R., \& Mohammed, S. (1994). Team mental model: Construct or metaphor? Journal of Management, 20, 403-437.

[41] Kozlowski, S. J., \& Bell, B. S. (2008). Team learning, development, and adaptation. In V. I. Sessa, \& M. Fondon (Eds.), Work group learning (pp. 15-45). NY: Lawrence Erlbaum.

[42] Kozlowski, S., \& Klein, K. (2000). A multilevel approach to theory and research in organizations: Contextual, temporal, and emergent processes. In K. Klein \& S. Kozlowski (Eds.), Multilevel theory, research, and methods in organizations: Foundations, extensions, and new directions (pp. 3-90). San Francisco: Jossey-Bass.

[43] Lam, S.S.K., \& Schaubroeck, J. A. S. (2002). Relationship between organizational justice and employee work outcomes: a cross-national study. Journal of Organizational Behavior, 23, 1-18.

[44] Larson J.R., Christensen C., Abbott A.S., Franz T.M. (1996). Diagnosing groups: charting the flow of information in medical decision making teams. Journal of Personality and Social Psychology, 71, 315-30

[45] Leenders, R.T., van Engelen, A.J., \& Kratzer, J., (2003) Virtuality, Communication, and New Product Team Creativity: A Social Network Perspective, Journal of Engineering and Technology Management, 20, 69-92.

[46] Marks, M.A., Sabella, M.J., Burke, C.S., \& Zaccaro, S.J. (2002). The impact of cross-training on team effectiveness. Journal of Applied Psychology, 87, 3-13.

[47] Mathieu, J. E., Goodwin, G. F., Heffner, T. S., Salas, E., \& Cannon-Bowers, J.A. (2000). The influence of shared mental models on team processes and performance. Journal of Applied Psychology, 85, 273-283.

[48] Mitchell, R., Boyle, B., \& Nicholas, S. (2009). The impact of goal structure in team knowledge creation. Group Processes \& Intergroup Relations, 12, 639-651.

[49] Mumford, M., Feldman, J., Hein, M., \& Nagao, D. (2001). Tradeoffs between ideas and structure: Individuals versus group performance in creative problem solving. Journal of Creative Behavior, 35, 1-23.

[50] Mumford, M.D., Mobley, M.I., Uhlman, C.E., ReiterPalmon, R., \& Doares, L.M., (1991). Process analytic models of creative thought. Creativity Research Journal, 4, 91-122.

[51] Pearce, C., \& Ensley, M. (2004). A reciprocal and longitudinal investigation of the innovation process: The central role of shared vision in product and process innovation teams (PPITs). Journal of Organizational Behavior, 25, 259-278.

[52] Rank, J., Pace, V. L. \& Frese, M. (2004). Three avenues for future research on creativity, innovation, and initiative. Applied psychology: An international review, 53, 518- 528.

[53] Rivlin, L.G. (1959). Creativity and the self-attitudes and sociability of high school students. Journal of Educational Psychology, 50, 147-152.

[54] Santanen, E.L., Briggs, R.O., \& Vreede, G.J. de (2004). Causal relationship in creative problem solving: Comparing facilitation interventions for ideation. Journal of Management Information Systems, 20, 167-197.

[55] Stacey, M. K., Eckert, C. M., \& Wiley, J. (2002). Expertise and creativity in knitwear design.
International Journal of New Product Development and Innovation Management, 4, 51-66.

[56] Stasser, G. \& Titus, W. (2006). Pooling of unshared information in group decision making: Biased information sampling during discussion. In John M. Levine \& Richard L. Moreland (Eds.), Small groups (pp.227-239). New York: Psychology Press.

[57] Stasser, G., Taylor, L.A., \& Hanna, C. (1989). Information sampling in structured and unstructured discussions of 3-person and 6-person groups. Journal of Personality and Social Psychology, 57, 67-78.

[58] Stein, M. I. (1965). Several findings of a transactional approach to creativity. In Steiner, G. A. (Ed.), The creative organization. Chicago, IL: University of Chicago Press

[59] Stout, R.J., Cannon-Bowers, J.A., Salas, E., \& Milanovich, D.M. (1999). Planning shared mental models, and coordinated performance: An empirical link is established. Human Factors, 41, 61-71.

[60] Tagger, S. (2002). Individual creativity and group ability to utilize individual creative resources: A multilevel model. Academy of Management Journal, 45, 315-330.

[61] Tesluk, P.E., Farr, J.L., \& Klein, S.R. (1997). Influences of organizational culture and climate on individual creativity. Journal of Creative Behavior, 31, 27-41.

[62] Thamhain, H.J. (2003). Managing Innovative R \& D Teams. $R$ \& D Management, 33, 297-311.

[63] Tiwana A, \& McLean E. (2005). Expertise integration and creativity in information systems development. Journal of Management Information Systems, 22, 13-43.

[64] Toma C., \& Butera F. (2009). Hidden profiles and concealed information: Strategic information sharing and use in group decision making. Personality and Social Psychology Bulletin, 35, 793-806.

[65] Vincent, P. H., Decker, B. P., \& Mumford, M. D. (2002). Divergent thinking, intelligence, and

[66] West, M. A., \& Anderson, N. R. (1996). Innovation in top management teams. Journal of Applied Psychology, 81, 680-693.

[67] Winquist JR, Larson JR. 1998. Information pooling: when it impacts group decision making. Journal of Personality and Social Psychology, 74, 371-77.

[68] Woodman, R. W., J. W. Sawyer, \& R. W. Griffin (1993). Toward a theory of organizational creativity. Academy of Management Review, 18, 293-321.

[69] Diehl, M., \& Stroebe, W. (1991). Productivity loss in idea-generating groups: Tracking down the blocking effect. Journal of Personality and Social Psychology, 61(3), 392-403.

[70] Nemeth, C. J. (1986). Differential contributions of majority and minority influence. Psychological Review, 93(1), 23-32.

[71] Majchrzak, A., Jarvenpaa, S. L., \& Hollingshead, A. B. (2007). Coordinating Expertise Among Emergent Groups Responding to Disasters. Organization Science, 18(1), 147-161. 